\title{
A NOTE ON OPERATIONISM
}

FRED WILSON

University of Toronto

Some defend the thesis that terms in the vocabulary of science are all definable on an observational base. Call one who defends this thesis a definitionalist. ${ }^{1}$ It has been claim. ed by some that the definitionalist cannot account for the addition of criteria to concepts." Thus, for example, temperature was, let us suppose, first defined by means of a mercury thermometer. This coud not be used everywhere, so the platinum resistance thermometer was introduced. The definitionalist must say that there are here two different concepts, since the criteria are different. Yet, clearly, there is but one concept, namely, temperature, of which these are both but criteria, and therefore the definitionalist's thesis cannot be correct. Or so the argument goes. It usually functions as a preliminary to the move toward so-called reduction sentences. Be that as it may, the argument is still a bad argument.

Suppose for a certain class $A$ of objects, temperature of an object is defined by means of the mercury thermometer. For $x$ in $A$ we have

(1) ' $T_{1}(x)=N$ ' is short for 'if $x$ is placed next to a mercury thermometer, then when the mercury reaches equilibrium the height of the column is $N^{\prime}$

1 For an excellent statement on the reasonable limits that must be placed on the definitionalist's thesis, see G. Bergmann, "Sense and Nonsense in Operationism," Scientific Monthly, 79, 1954, pp. 210-215.

2 For example, Hempel argues in this fashion. Cf. Fundamentals of Concept Formation in Empirical Science Chicago, University of Chicago Press, 1952, pp. 28.29. 
(I shall explain the subscript in a moment).

Suppose it is also true that for objects in class $A$, their density (say) is some definite function $f_{1}$ of their temperature. That is, suppose that for objects $x$ of class $A$, we have the law

(a) $D(x)=f_{1}\left(T_{1}(x)\right)$

The law (a) renders the definiendum of (1) of interest to the scientist. For the scientist is interested in discovering and stating laws. It follows that he is interested in only such concepts as appear in statements of law. To say the same thing differently, the scientist is interested in defining, or giving meaning to, only such concepts as occur in laws, or, synonymously, have meaning. (a) provides the meaning? for the concept for which (1) provides the meaning..

Suppose now that there is a class of objects $B$ such that $A$ overlaps but does not exhaust $B$. Suppose further that the scientist is interested in the density of objects in $B$. He will try to find something analogous to (a) for the whole of class $B$, since he already has (a) for part of it, namely the part that overlaps $A$. After discovering (b) and (c) [see below], he would offer the following definition for temperature of $x$ in $B$ :

(2) ${ }^{\prime} T_{2}(x)=N$ ' is short for 'if $x$ is connected to a platinum resistance thermometer, then the resistance is $N^{\prime}$

This will count as a case of defining temperature only in case that, with the appropriate standards and calibrations, we have for all $x$ in the class $A \& B$

$$
T_{1}(x)=N \equiv T_{2}(x)=N
$$

Suppose (b) is true. It states that in the overlap of $A$ and $B$, the two ways of measuring yield the same result.

Suppose, finally, that it has also been discovered that, for all $x$ in $B$, it is true that 


$$
D(x)=f_{1}\left(T_{2}(x)\right)
$$

From (b) and (c) we can now deduce that for any $x$ in $A \& B$,

$$
D(x)=f_{1}\left(T_{1}(x)\right)=f_{1}\left(T_{2}(x)\right)
$$

The scientist now has (b) giving meaning: to both the definiendum of (1) and that of (2). Furthermore, he has (b) and (c) giving meaning. to the definiendum of (2). Derivatively from this he has (d) giving meaning 2 to both concepts. Finally, the functional relationship of both to the density is the same.

This would permit the scientist to define

$$
{ }^{\prime} T_{1}(x)=N \text { ' is short for ' } T(x)=N \cdot v \cdot T_{2}(x)=N '
$$

From this we have immediately that, for any $x$ in $A \mathrm{v} B$

$$
\begin{aligned}
& T_{1}(x)=N \supset T(x)=N \\
& T_{2}(x)=N \supset T(x)=N
\end{aligned}
$$

(b) guarantees the success of (3). By virtue of it, there will be no $x$ in $A \& B$ such that $T_{1}(x)=N_{1}$ and $T_{2}(x)=N_{2}$, $N_{1} \neq N_{2}$. Thus there will be no $x$ in $A \& B$ such that $T(x)=N_{1}$ and $T(x)=N_{2}, N_{1} \neq N_{2}$. The introduction of the functor by (3) is therefore permissible.

(a), (b), and (c) permit the derivation of the law that, for any $(x)$ in the union $A \mathrm{v} B$ of the classes $A$ and $B$,

(g) $\quad D(x)=f_{1}(T(x))$

(g) gives meaning 2 to the definiendum of (3).

Originally, the scientist would refer to the definiendum, $T_{1}$ of (1) as "temperature." But he searches for, and discovers, certain laws, in particular, (b) and (c). This leads him to introduce the definiendum of (2); he has discovered that this has meaning2 also. By virtue of (b) the same result is obtained in the overlap of $A$ and $B$ by both measuring techniques. By virtue of (c), and therefore of (d), the definien- 
dum, $T_{2}$ of (2) stands in the same functional, i.e., lawful, relationship to density as does $T_{1}$. This leads the scientist to call $T_{2}$ a new criterion for "temperature." That is, he redefines "temperature" to mean what is defined by (3), instead of, as originally, (1).

What was formerly the complete definiens of temperature becomes but part of the definiens when the concept of temperature is redefined upon the discovery, by the scientist, of certain laws. The definitionalist can therefore account for the fact that the scientist adds criteria of application to his concepts as he comes to discover more laws. He can account for the fact that the scientist extends his concepts via new criteria of application in such a fashion that they come to apply in regions where originally they did not apply.

It remains nonetheless true that the adding of new criteria gives a new concept. The concept defined by (3) has a meaning $_{1}$ which is not the meaning ${ }_{1}$ of the concept defined by $(1)$. This the definitionalist is clearly committed to. What he must also do is account, non-trivially, for the idea that there is but one concept involved, or, what ammounts to the same, why the same word is defined by (1) and then redefined by (3). This the definitionalist does by indicating certain aspect of the meaning ${ }_{2}$ of the definienda.

Consider the definiendum of (1) and that of (3). By virtue of (e), they always yield the same result. Only, the definiendum of (3) applies to a broader class of entities, namely, those in $A \mathrm{v} B$, than does that of (1). But more crucially: for all the entities in this broader class $A v B$, the definiendum of (3) stands in exactly the same functional relationship to density as does the definiendum of (1) to the density of objects in the smaller class $A$; that is, $(\mathrm{g})$ is of the same form as (a). The fact that knowledge has grown in this way, from (a) through (b) and (c) to (g), provides a non-trivial account of the idea that there is but one concept of temperature involved.

To be sure, the account is not in terms of logic. So far as 
logic is concerned, there are two different definienda of "temperature." But not everything is a matter of logic. Indeed the reason why we define as we do is never a matter of logic. It may be that we define a word in a certain way in order to influence the behaviour of others; thus we have the so-called persuasive definitions. It may be that the scientist defines a word in a certain way because he has discovered the term thus defined has meaning. It may be that both are involved. But whatever the reason is, it is not drawn from logic. There is, therefore, nothing untoward in the definitionalist's attempt to account for "temperature" being redefined as indicated in terms of what the scientist comes to discover about the mean. ing $_{2}$ of the concepts he is using. ${ }^{3}$

3 For a discussion of some other aspects of the issues involved, see chapters four and five of my extended study, "The Notion of Logical Necessity in the Later Philosophy of Rudolph Carnap," in A. Hausman and F. Wilson, Carnap and Goodman: Two Formalists, The Hague, Nijhoff, (forthcoming). 


\section{NOTA SOBRE EL OPERACIONALISMO *}

FRED WILSON

Algunos autores defienden la tesis de que todos los términos del vocabulario de la ciencia son definibles sobre la base de observa. ciones. Llamemos a un defensor de esta tesis "definicionista". Algunos han sostenido que el definicionista no puede explicar la adición de criterios a los conceptos. Así, por ejemplo, supongamos que la temperatura fue definida primero mediante un termómetro de. mercurio. Este no podía usarse en todas las ocasiones, por lo tanto se introdujo el termómetro con resistencia de platino. El definicionista tiene que decir que hay dos conceptos diferentes, puesto que los criterios son diferentes. Con todo, es claro que sólo hay un concepto, el de temperatura, respecto del cual los anteriores sólo son criterios, en consecuencia, la tesis del definicionista no puede ser correcta. De este modo reza el argumento. Comúnmente funciona como un paso preliminar para proceder a las llamadas "oraciones reductivas". Sea lo que fuere, se trata de un mal arguinento.

Supongamos que para cierta clase $A$ de objetos, se define la temperatura de un objeto mediante el termómetro de mercurio. Para un $x$ de $A$ tenemos:

(1) ' $T_{1}(x)=N$ ' es una abreviación de 'Si $x$ está situado cerca de un termómetro de mercurio, entonces, cuando el mercurio alcance un equilibrio, la altura de la columna es $N^{\prime}$

(Explicaré enseguida el 1 suscrito).

Supongamos que también es verdad que para los objetos de la clase $A$, su densidad (por ejemplo) es una función definida $f_{1}$ de su temperatura. Es decir, supongamos que para los objetos $x$ de laclase $A$, tenemos la ley:

(a) $D(x)=f_{1}\left(T_{1}(x)\right)$

La ley (a) vuelve interesante para el científico el definiendum

* Dada la brevedad del artículo del señor Fred Wilson, publica. mos una traducción completa al español, en lugar del resumen acostumbrado (El Comité de Dirección). 
de (1). Pues el científico está interesado en descubrir y establecer leyes. En consecuencia, está interesado solamente en conceptos que figuran en enunciados de leyes. En otras palabras, el científico está interesado en definir o en dar un significado ${ }_{1}$ solamente a los conceptos tal como figuran en las leyes o, lo cual es sinónimo, a los conceptos que tienen un significado $o_{2}$. (a) suministra el significado al concepto al cual ( 1 ) le suministra el significado . $_{\text {. }}$

Supongamos ahora que hay una clase de objetos $B$ tal que $A$ se sobrepone a $B$ pero no la agota. Supongamos además que el cientí. fico está interesado en la densidad de los objetos de $B$. Tratará de encontrar algo análogo a (a) para la totalidad de la clase $B$, pues. to que ya tiene (a) para parte de ella, a saber, para la parte que se sobrepone a $A$. Después de descubrir (b) y (c), ofrecerá la siguiente definición de la temperatura de un $x$ de $B$ :

(2) ' $T_{2}(x)=\mathrm{N}$ ' es una abreviación de ' $\mathrm{Si} x$ está conectado a un termómetro de resistencia de platino, entonces la resisten. cia es $N^{3}$

Esto valdría como un caso de definición de temperatura sólo si, con las medidas y calibraciones apropiadas, tenemos para todo $x$ en las clases $A \& B$,

(b) $T_{1}(x)=N \equiv T_{2}(x)=N$

Supongamos que (b) es verdadera. Enuncia que en la parte en que se sobreponen $A$ y $B$, los dos modos de medición arrojan el mis. mo resultado.

Supongamos, por fin, que también se ha descubierto que, para todo $x$ de $B$, es verdadero que

(c) $D(x)=f_{1}\left(T_{2}(x)\right)$. $\& B$,

De (b) y (c) podemos ahora deducir que, para cualquier $x$ de $A$

$$
\text { (d) } D(x)=f_{1}\left(T_{1}(x)\right)=f_{1}\left(T_{2}(x)\right)
$$

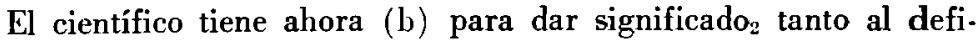
niedum de (1) como al de (2). Más aún, tiene (b) y (c) para dar significado $_{2}$ al definiendum de (2). De lo cual se sigue que tiene (d) para dar significado ${ }_{2}$ a ambos conceptos. Por fin, la relación funcional de ambos con la densidad es la misma.

Esto permitirá al cientifico definir:

(3) ' $T(x)=N$ ' es una abreviatura de ' $T_{1}(x)=N . v . T_{2}(x)=\mathrm{N}$ '

De esto se sigue inmediatamente que, para cualquier $x$ de $A v B$, 
(e) $T_{1}(x)=N \supset T(x)=N$

(f) $T_{2}(x)=N \supset T(x)=N$

(b) garantiza el éxito de (3). Gracias a él no habrá ninguna $x$ de $A \& B$ tal que $T_{1}(x)=N_{1}$ y $T_{2}(x)=N_{2}, N_{1} \neq N_{2}$. Así no habrá ningún $x$ de $A \& B$ tal que $T(x)=N_{1}$ y $T(x)=N_{2}, N_{1} \neq N_{2}$. $\mathrm{La}$ introducción del functor en (3) es, por consiguiente permisible.

(a), (b) y (c) permiten derivar la ley de que, para cualquier $x$ en la unión, $A$ v $B$, de las clases $A$ y $B$,

(g) $D(x)=f_{1}(T(x))$.

(g) da un significado. al definiendum de (3).

Al principio, el científico se referiria al definiendum, $T_{1}$, de (1) como "temperatura". Pero busca y descubre ciertas leyes, en parti. cular (b) y (c). Esto lo lleva a introducir el definiendum de (2); ha descubierto que éste tiene también un significado. En virtud de

(b) se obtiene el mismo resultado en la parte en que se sobreponen $A$ y $B$, con ambas técnicas de medición. En virtud de (c) y, por ende, de (b), el definiendum, $T_{2}$, de (2) tiene con la densidad la misma relación funcional, esto es, legal que $T_{1}$. Esto lleva al científico a llamar a $T_{2}$ un nuevo criterio para "temperatura". Es decir, redefine "temperatura" para que signifique lo definido por (3), en vez de lo definido por (1), como al principio.

Lo que antes era el definiens completo de temperatura se convierte en sólo una parte del definiens, cuando se redefine el concepto de temperatura en base al descubrimiento de ciertas leyes por el científico. El definicionista puede, por lo tanto, explicar el hecho de que el científico añade criterios de aplicación a sus conceptos cuando llega a descubrir más leyes. Puede explicar el hecho de que el científico amplía sus conceptos mediante nuevos criterios de apljcación, de tal manera que llegan a aplicarse a regiones a las que en un principio no se aplicaban.

Sin embargo, es cierto que la adición de nuevos criterios suministra un nuevo concepto. El concepto definido por (3) tiene un significado $_{1}$ que no es el significado $_{1}$ del concepto definido por (1). A esto se ha comprometido abiertamente el definicionista. Lo que también tiene que hacer es explicar, de una manera no trivial, la idea de que sólo se trata de un concepto o, lo que es igual, debe explicar por qué la misma palabra es definida por (1) y luego redefinida por (3). Cosa que hace el definicionista indicando ciertos aspectos del significado: de los definienda.

Consideremos el definiendum de (1) y el de (3). En virtud de 
(e), arrojan siempre el mismo resultado. Sólo que el definiendum de (3) se aplica a una clase de entidades más amplia, las de $A \cup B$, que el definiendum de ( 1 ). Lo que es más importante: para todas las entidades en esta clase más amplia, $A$ v $B$, el definiendum de (3) tiene exactamente la misma relación funcional con la densidad que el definiendum (1) tiene con la densidad de objetos de la clase más estrecha $A$, es decir, (g) tiene la misma forma que (a). El hecho de que, de esa manera, ha aumentado el conocimiento, de (a) a (g) al través de (b) y (c), suministra una explicación no trivial de la idea de que sólo se utiliza un concepto de temperatura.

De seguro, la explicación no se formula en términos de lógica. Por lo que concierne a la lógica, hay dos diferentes definienda de "temperatura". Pero no todo es asunto de lógica. En verdad, la razón por la que definimos como lo hacemos nunca es un asunto de lógica. Puede suceder que definamos una palabra de cierta manera para influir en el comportamiento de los demás; tenemos, así, las llamadas "definiciones persuasivas". Puede ser que el científico defina una palabra de cierto modo porque ha descubierto que el término así definido tiene un significado ${ }_{2}$. Y puede suceder que se trate de ambos casos. Pero cualquiera que sea la razón, ésta no se deriva de la lógica. No hay, por lo tanto, nada desfavorable en el intento del definicionista por explicar la redefinición de "temperatura" en términos de lo que llega a descubrir el científco acerca del significado ${ }_{2}$ de los conceptos que utiliza. 